\title{
20 ANOS DE UNIVERSIDADE CATÓLICA
}

\section{EM VISEU}




\section{ANOS DE UNIVERSIDADE CATÓLICA EM VISEU JUBILEU DO ANO 2000}

\section{PROGRAMA DE CELEBRAÇÕES}

\section{INÍCIO DAS COMEMORAÇÕES}

1. Preparação e divulgação de um texto sobre o dia da U.C.P. e sobre o programa comemorativo dos 20 anos da sua presença em Viseu, a ser divulgado na nossa comunidade académica, nos meios locais e enviado aos párocos da Diocese de Viseu.

Este texto, assinado pelo Presidente do C.R.B., será publicado até 20/01/2000 e nele se dirá da disponibilidade de alguém para participar em qualquer acção de esclarecimento sobre a Universidade Católica que os párocos ou as paróquias entenderem organizar.

2/02/2000 - Quarta-feira, quatro dias antes do dia da U.C.P., às 18h00

2. Abertura das comemorações do $20^{\circ}$ aniversário da U.C.P., em Viseu, com as seguintes intervenções:

a) Historial da vinda para Viseu da U.C.P., até à constituição do C.R.B..

b) Lugar e funções da Universidade, no mundo do próximo milénio.

6/02/2000 - Domingo, dia da U.C.P.

3. No dia 6, Domingo, dia da Universidade Católica, Celebração Eucarística presidida pelo Bispo da Diocese na Sé Catedral, às $11 \mathrm{~h} 00$, para a qual se convida a Comunidade Académica.

\section{PREPARAÇÃO E CELEBRAÇÃO DA PÁSCOA/2000}

Tema: Presença do Cristianismo na assistência e promoção social. 


\section{5/03/2000 - Quarta-feira, 18h00}

1. A acção social na região de Viseu. Colaboração do Centro Regional de Segurança Social e Instituições da Igreja: filosofia, programas em execução, perspectivas.

\section{2/03/2000 - Quarta-feira, às $18 \mathrm{~h} 00$}

2. Presença cristã na Universidade, no passado e no presente.

a) O papel da Igreja na génese da Universidade em Portugal.

b) Presença cristã na Universidade no passado e actualmente.

\section{9/03/2000 - Quarta-feira, às 18h00}

3. Encontro do Bispo com os professores da Universidade Católica - Pólo de Viseu, preparando o dia do Jubileu Diocesano dos professores.

Tema: As nossas responsabilidades como Universidade Católica perante a Sociedade e perante a Igreja. O que pedimos à Igreja.

2/04/2000 - Domingo, às $11 \mathrm{~h} 00$

4. Jubileu dos professores da Diocese de Viseu, com celebração na Sé presidida pelo Bispo.

\section{5/04/2000 - Quarta-feira, às $18 \mathrm{~h} 00$}

5. Presença cristã nos Serviços de Saúde. O que pede este dobrar de milénio. Mesa-redonda, com participação de:

a) Responsável nacional da Pastoral da Saúde

b) Membros da Comissão Diocesana da Pastoral da Saúde

12/04/2000 - Quarta-feira, às $18 \mathrm{~h} 00$

6. Celebração Pascal da Universidade.

\section{A UNIVERSIDADE CATÓLICA EM VISEU JUBILEU DO ANO 2000}

\section{3/05/2000 - Quarta-feira, às 18h00}

1. O Nascimento da Universidade Católica Portuguesa e o espaço que pretendeu ocupar no mundo universitário em Portugal.

\section{$10 / 05 / 2000$ - Quarta-feira, às $18 \mathrm{~h} 00$}

2. Passado, presente e futuro da U.C.P., em Viseu, pelo presidente do C.R.B., seguida da inauguração da Exposição "20 anos de U.C.P. em Viseu". 


\section{4/05/2000 - Domingo, às $11 \mathrm{~h} 00$}

3. Participação na cerimónia da benção dos finalistas do Ensino Superior, em Viseu.

4. Comemoração da abertura solene da Universidade Católica em Viseu, há 20 anos.

4.1. 2 Peças de Teatro Grego, em data a definir.

11/11/2000 - Sábado, início às $10 \mathrm{~h} 00$

4.2. Encontro de antigos alunos da U.C.P. - Viseu, promovido pela Universidade, com:

a) recepção pelo Presidente.

b) mesa redonda com experiências profissionais de licenciados pela U.C.P. - Viseu, motivando a participação de outras experiências.

c) perspectivas futuras de relação mais continuada dos antigos alunos com a U.C.P..

\section{$16 / 11 / 2000$ - Quinta-feira, início às $16 \mathrm{~h} 00$}

5. Jubileu da Universidade Católica - Viseu

a) Eucaristia presidida pelo Bispo.

b) Sessão solene comemorativa dos vinte anos da Universidade Católica em Viseu, com intervenções:

1. das autoridades académicas;

2. das forças vivas da cidade;

3. de licenciados pela universidade.

c) Inauguração de um espaço onde possa figurar, em exposição permanente, o desenvolvimento passado e futuro da U.C.P., em Viseu. 